\title{
Volcanic Activity
}

\section{in the}

\section{Aleutian Arc}

By ROBERT R. COATS

CONTRIBUTIONS TO GENERAL GEOLOGY, 1950

GEOLOGICAL SURVEY BULLET IN 974-B

Including a list of all.known volcanoes and a summary of activity between 1760 and 1948

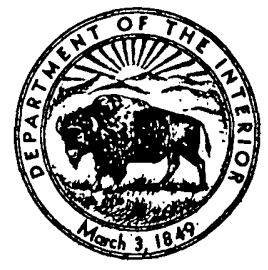


UNITED STATES DEPARTMENT OF THE INTERIOR

Oscar L. Chapman, Secretary

\section{GEOLOGIGAL SURVEY}

W. E. Wrather, Director 


\section{CONTENTS}

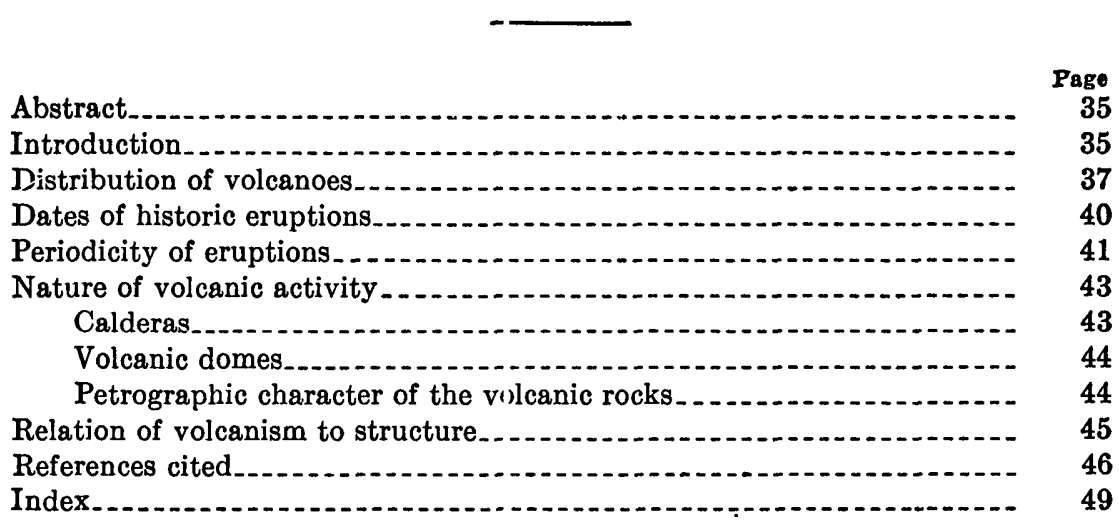

\section{ILLUSTRATIONS}

Plate 1. Map of the Aleutian Islands and the Alaska Peninsula, showing the location of the principal volcanoes............... In pocket

Figure 16. Five-year moving avere.ges of numbers of volcanoes in erup-

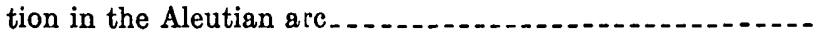

\section{T'ABLES}

TABLE 1. Volcanoes of the Aleutian arc .

2. Summary of volcanic activity in the Aleutian arc, 1760-1948. In pocket

3. Calderas of the Aleutian erc .

$889513-50$

III 



\title{
VOLGANIG AGTIVITY IN THE ALEUTIAN ARC
}

\author{
By Robirit R. COATs
}

\section{ABEITRACT}

At least 76 major volcanoes, active and extinct, have been recognized in the Aleutian arc, extending from Buldir :island on the west to Mount Spurr on the east. Of these, 36 are indicated as having been active since 1760 . When plotted

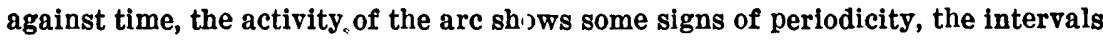
between maxima being multiples of 20 years. In this report the geographic positions and altitudes of all the known volcanoes are tabulated, together with all known eruptive activity between $: 1760$ and 1948 . The kind of activity that has characterized the arc is describel briefly; a list of 17 calderas, 9 of them hitherto unmentioned in the literature, is given; and the relation of volcanism to the structure of the arc is reviewed.

\section{INTRODUCTION}

This report is intended to present a brief summary of the present state of geographic and volcarologic information concerning the volcanoes of the Aleutian arc. It deals with the place, time, and nature of the activity of those volcanoes whose foci of eruption still are easily discernible and whose products form conspicuous, individualized landscape features at th" present day. The term "Aleutian arc" is here used to include the entire arc of the Aleutian Islands and its structural extensions, the Alaska Peninsula and the Aleutian Range.

Of the volcanic arcs that fringe the Pacific Ocean, that which stretches from Buldir Island to Mount Spurr is one of the least known. Remoteness from centers of population and the disagreeable climate have combined to discourage geclogists from undertaking the study of this chain of volcanoes. The energies of Government geologists have been largely focused on problems that appeared to be of more immediate economic interest, and from this standpoint there was little justification for the study of these volcanoes. In the eastern part of the arc, studies have been made of mineral deposits and of the occurrence of petroleum in the older rocks that form the foundation on which the volcanoes sit, but in the western part of the arc, in the Aleutian Islands proper, there sppeared to be little to beckon the prospector or to justify geologic studies intended to assist him.

Until the middle of the nineteenth century, most of the information on the volcanoes of the arc had been derived from the more or less 
casual observations of geologists or other scientists attached to several exploring expeditions; this information was summarized by Grewingk (1850), whose compilation has been the most useful and accessible source of information on the Aleutian arc to that date. Since the publication of Grewingk's volume, the principal sources of information have been the reports of Dall (1918), of Becker (1898), and of several Survey geologists, who, while engaged in petroleum investigations on the Alaska Peninsula, made incidental observations on the volcanoes. Especially worthy of mention are W. W. Atwood, W. R. Smith, A. A. Baker; R. S. Knappen, and F. H. Moffit. The famous eruption of Katmai in 1912 led to much careful work in that area by Griggs (1921), Fenner, and their associates.

The events of the recent war have magnified the importance of the Aleutian arc in the geography of war and peace. Enormous sums of money have been spent in the development of army: and naval bases and of airfields adequate for heavy bombers and transport planes. The chain of bases extends the entire length of the Alaska Peninsula and the Aleutian Islands. In these circumstances, the temporal and spatial distribution and the nature of the volcanic activity along the arc become of considerable importance to those who are responsible for the installations and for the personnel in this area, which during the war was, in all probability, more densely populated than at any time in its previous history.

The importance of a knowledge of the volcanoes of the arc was emphasized dramatically by the eruption, beginning in June 1948, of a small cone within the great caldera of Okmok on Umnak Island. As a consequence of this eruption, which was reported by Robinson (1948), the United States Geological Survey undertook a program of volcanologic studies in the Aleutian Islands and the Alaska Peninsula. This program began in the fall of 1945 . The assembling of all available data on the earlier volcanic activity was considered a necessary preliminary to field work, and this report represents that compilation, modified to some extent by the results of field work done in the summers of 1946,1947 , and 1948.

The writer's field work has been limited to the western Aleutians; therefore, statements concerning other parts of the arc are based on published information, on a study of aerial photographs, or on information contributed by colleagues in the Geological Survey. The author is particularly indebted to Frank S. Simons, who worked on Great Sitkin; David M. Hoplkins, who worked on Umnak; Frank M. Byers, Jr., who has mapped extensively on Umnak, Unalaska, Akun, and Akutan; and George C. Kennedy and H. H. Waldron, who provided information concerning the activity of Frosty and the volcanoes of the Pavlof area. 


\section{DISTRIBUTION OF VIOLCANOES}

The known geologic record in the Aleutian arc extends, with great gaps, as far back as the late Paleozoic; it is dominated throughout by volcanic rocks and sediments derived from them. The gaps are due in part to conditions unfavouable for the preservation of fossils, in part to a paucity of exposures, and in part to incomplete geologic studies. Because of limited exposures, little can be said about the geographic distribution of the older volcanic activity, but the youngest cones, as has been previously not id by many observers (Capps, 1934, p. 146), are restricted in their (spatial distribution with respect to the axis of the arc (pl. 1). In the western part of the arc, as far east as Akutan, these volcanoes liend to lie to the north of the older volcanic rocks of the Aleutian Islands. Along Unimak Island and the Alaska Peninsula, they lie in general along the axis of the peninsula as far northwest as Mount Peulik, beyond which the main axis of the peninsula is northwest of the volcanic arc.

About:76 major volcanoes are spread in the broad arc that extends about 1,700 miles from Buldir Is]and, eastward through the Aleutian Islands, along the Alaska Peninisula and the mainland of Alaska to Mount Spurr. Both active and extinct volcanoes are included, but all form independent structures of considerable size and either are known to have been active in historic time or show features indicating that they were probably active in. Pleistocene or Recent time. Most of them are shown on the acconpanying map (pl. 1), and all are listed with their heights and positions in the following table. The latitude and longitude given refer in some instances to the highest point on the caldera rim; in ot'lers, to the highest cone occupying the caldera. The 36 volcanoes raarked with an asterisk $\left({ }^{*}\right)$ are believed to have been active in historic time-that is, since 1760 .

The names of numerous supposed volcanoes that have appeared in the literature have been omitted :rom the foregoing list; sufficient information is now at hand to discredit many reported discoveries. Some of them were probably duc to the inaccurate location of actual volcanoes, others to a confusion. in names, and still others to the mistaken identification of fog streamers and cloud caps as eruption clouds. In many earlier lists, toc, actual volcanic centers in fumarolic stages have been reported as active volcanoes because of the confusion of fumarolic steam with an eru tion cloud. For this reason, some volcanoes for which eruptions have been reported are here removed from the class of active volcanoes.

Sitignak Island, listed by Sapper (1927, p. 338) on Grewingk's authority as the site of an eruptio in 1776, does not correspond with any existing island, as Sapper himself remarks; nor does Rat Island, which Sapper suggests as the most probable site of the reported erup- 
TABLE 1.-Volcanoes of the Aleutian arc

[Arranged in geographic order from west to east]

\begin{tabular}{|c|c|c|c|c|}
\hline NaI & Geographic locality & Latitude & Longitude & $\begin{array}{l}\text { Altitude } \\
\text { (meters) }\end{array}$ \\
\hline 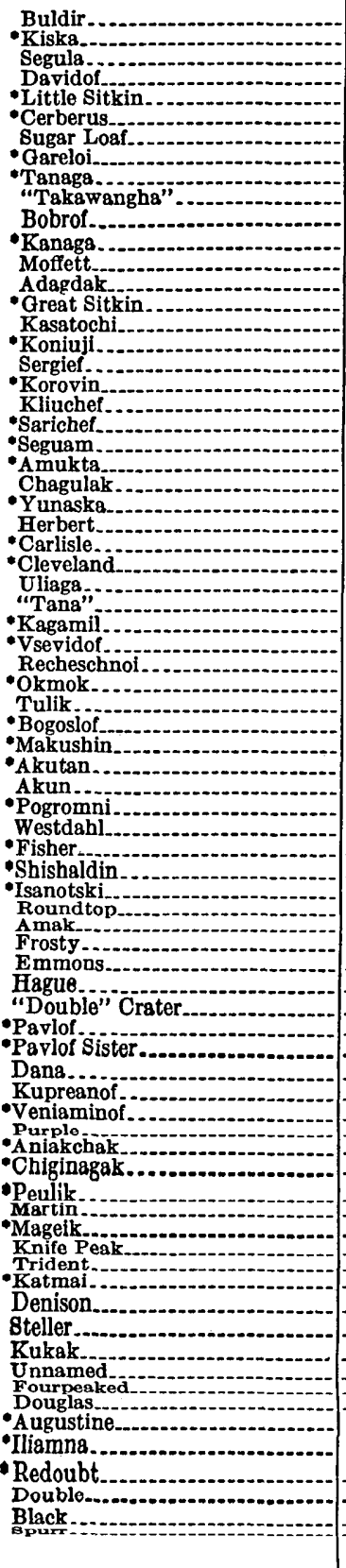 & 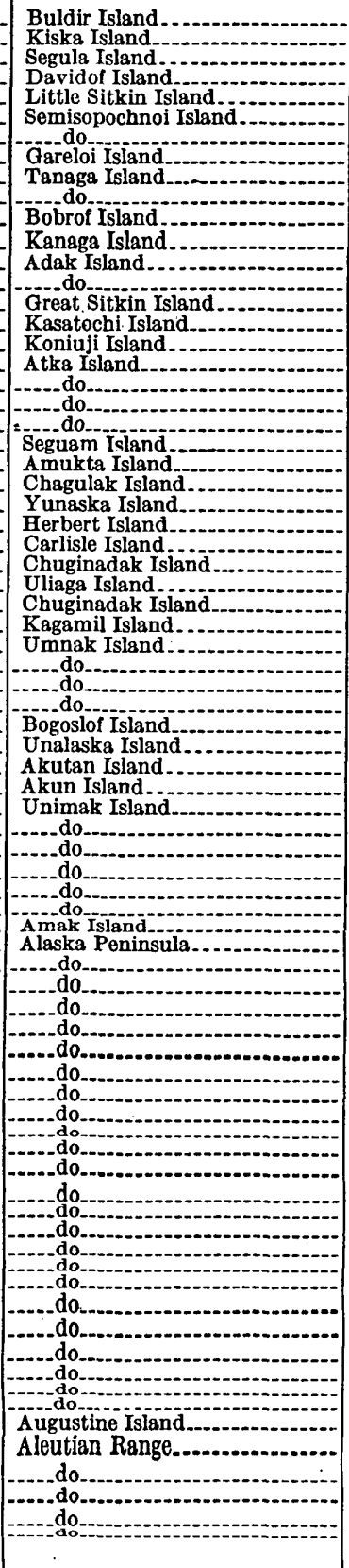 & 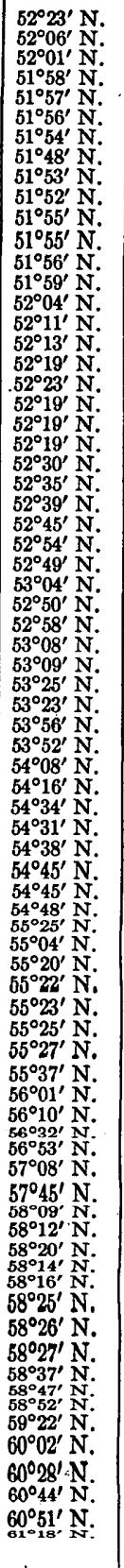 & 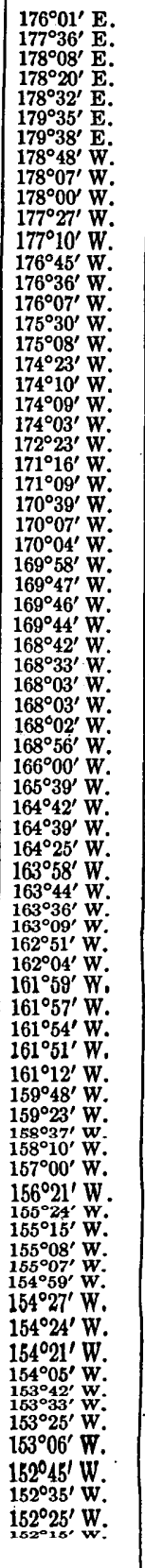 & 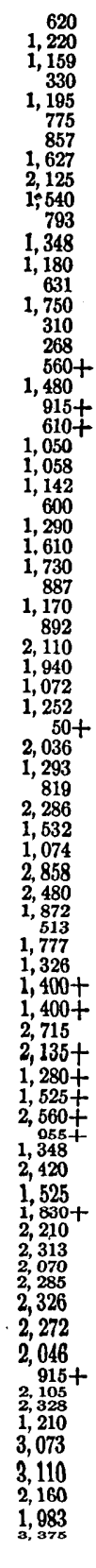 \\
\hline
\end{tabular}


tion, appear to have been the sitz of any geologically recent volcanic activity. The eruption reported. by Grewingk probably should have been, and is here, attributed to Little Sitkin.

Adak Island (Sapper, 1927, j). 338), given in some compilations as the location of a so-called White Mountain or White Volcano active in 1760 and 1784, has certainly not been the site of any eruption in geologically recent time. The ascription of the White (Belaya) Volcano to Adak is probably due to a misreading by some geologist of an early report by Vasyutinsky. This interpretation is suggested by the wording of the translation of his report by Jochelson (1933, p. 7), in which it is not made quite clear whether the mention of the White Mountain refers to Adak Island or Great Sitkin Island. The Great Sitkin volcano is much higher than any mountain on Adak and, with its permanent glaciers and Jarge snow fields, merits the adjective "white."

Mount Dutton (Medvenikovsliy), at latitude $55^{\circ} 08^{\prime} \mathrm{N}$., longitude $162^{\circ} 04^{\prime}$ W., has been described as a volcano (Sapper, 1927, p. 341), but according to G. C. Kennedy and $\mathrm{H}$. H. Waldron, who mapped that area in 1946, it is not volcanic. Moreover, several volcanoes are mistakenly indicated on a map accompanying a report by P. S. Smith $(1939$, pl. 16) ; Kagalaska Island is certainly not the site of any volcano, Conical Mountain on Atka Island is not a volcano, and Alai Mountain-according to Jacob Ireedman, who worked. in the areais not volcanic. Walrus Peak (Morshowsky), at latitude $54^{\circ} 59^{\prime} \mathrm{N}$, longitude $162^{\circ} 51^{\prime} \mathrm{W}$., has been :eported (Becker, 1898) as active in 1768 but also is nonvolcanic.

The geodetic positions of the summits of the volcanoes have been scaled from Aleutian Islands Fliç, Charts 1, 2, and 3 of the Army Air Force's 1944 editions. In a few instances, more accurate data were obtained from later maps, principally detailed topographic maps prepared by the Army engineers. The flight charts also are sources for most of the heights given on plate 1, but more recent information from the Coast and Geodetic Suj'vey has introduced a few differences between the figures on the map a:ld those in the table, which embodies changes made since the drafting of the map. Where summit elevations were determined by the hirghest closed contour on the map, the value of this contour is used for the height, with a plus sign $(+)$ to indicate the approximation. As the contour heights on existing maps are given in feet, the figures in meters are not in even hundreds or thousands.

An attempt was made to determine whether there is any regularity or system to the spacing of active and probably active volcanoes along the principal arc. The distanzes separating successive volcanoes 
shown on plate 1 were tabulated by class intervals of 5 kilometers. No well-defined mode is present. Many of the distances fall in class intervals of 10 kilometers or under; these distances are appropriate for subsidiary and parasitic centers about a main focus of eruption. Other distances fall in class intervals up to 130 kilometers. Certain differences are more apparent when the arc is divided into three segments-one from Buldir to Seguam, one from Seguam to Dana, and one from Dana to Redoubt. In the first segment the class intervals between 56 and 75 kilometers are best filled; in the third segment those from 46 to 75 are best filled. On the average, the volcanoes are more closely spaced in the central part of the arc; insofar as closeness of spacing of active centers is a measure of the degree of activity, this part of the arc may be considered the most active segment. As will be shown later, this segment also contains the volcanoes for which the historic record of activity is most voluminous.

\section{DATES OF HISTORIC ERUPTIONS}

The dates of the known eruptions in the Aleutian arc from 1760 to 1948 are shown in the "Summary of volcanic activity in the Aleutian arc" that constitutes table 2. Data concerning the past activity of the active volcanoes listed on page 38 were largely derived from the references given at the end of the report and from notes in three periodicals-the United States Weather Bureau's Climatological Data, Alaska Section, volumes 1-34 (1914-48); Volcano Letters 1-502 (1925-48) of the Hawaiian Volcano Research Association; and the Zeitschrift für Vulkanologie, Bände 1-17 (1914-38), published in Berlin. The primary sources of information were published records of explorations containing eyewitness accounts of eruptions, newspaper reports quoting accounts obtained from eyewitnesses, official weather reports and other scientific findings, and first-hand manuscript reports from observers. The principal secondary sources were summaries, obtained chiefly from the technical press.

Numerous gaps and inaccuracies are undoubtedly present in the information gathered from so many and such diverse sources. The literate population of the Aleutian Islands, until the beginning of the recent emergency, has never been large, and most of it has been concentrated in a few villages for the greater part of the year. Moreover, the weather is not favorable for observations. The same conditions exist in lesser degree throughout the Alaska Peninsula, although there the activity of the salmon fishermen has provided opportunity for observations that otherwise would not have found their way into the literature. No newspapers of general circulation are published in that part of Alaska, and published local records are practically non- 
existent. Many of the earlier descriptions of volcanoes are in Russian and have been accessible to the author only in translation.

One probable source of much ccnfusion in the record is the popular tendency to call the cloud that results from the condensation of water vapor "smoke." When the accornpanying summary of volcanic activity was compiled, the extent of this confusion was not realized. Because of it, an undetermined part of all records that do not specify the nature of the activity, as well as all the records that indicate "smoke," should be regarded with considerable suspicion.

Some volcanoes that hitherto hive been listed as historically active are therefore relegated to the solfataric class. Akun, for example, has been reported active by Grewingk and Sapper, but F. M. Byers, Jr., told the author in 1948 that $i$; has almost certainly been in a solfataric stage during all of historic time. Kukak (Kutlyukhat, Kugak, Kugat) also has been reported in a solfataric stage, and one report of ash eruption (Doroshin, 1870) was doubtfully attributed to this peak; but as Kukak is deeply glaciated, "he report is perhaps erroneous.

Still other volcanoes that have been listed as active may be considered suspect. The depth of erosion on Koniuji suggests that the report of its activity may be wrong, and the ascription of an eruption: to Fisher Caldera may not be justified. This ascription is based on a statement by Grewingk (1850, pp. 113-114) that is very indefinite as to location; however, Grewingk distinguishes all the other well-defined. volcanoes on Unimak Island, and his mention of white ash suggests that this may have been the caldera-forming eruption. Great thicknesses of light-colored ash are now present on the slopes of the mountain around the caldera; psesumably they accumulated at the time the caldera was formed.

On the basis of the type of in tormation available, discrimination between major and minor explosive eruptions is very difficult. Probably many inaccuracies that may be attributed to this difficulty are present in the summary as given.

\section{PERIODICITY OF ERUPTIONS}

Figure 16 shows 5-year moving sverages of the numbers of volcanoes in eruption in the Aleutian arc. Successive points were plotted at 1-year intervals on the time scale, each point representing the average number of volcanoes in eruption fior the year plotted and the two preceding and two succeeding years. The points have been connected by a solid line.

Inspection of the graph indicates fairly well defined maxima in the years $1768,1790,1828,1908$, and 1929 . The corresponding successive intervals are $22,38,80$, and 21 year.s, respectively. The curve suggests, 
also, that the higher the peak of activity, the longer the period of relative repose before the next maximum, but several objections may be raised against the unequivocal acceptance of the apparent demonstration, of periodicity.

1. For the period of the Russian occupation of Alaska, most of the recorded information concerning volcanic eruptions is in the scientific publications resulting from a very small number of exploring expeditions. Two of these expeditions, those of Billings and Lütke, coincide approximately with two maxima indicated on figure 16 . The times of other expeditions, however, show no discernible relationship to maxima.

9. The long and nearly complete hiatus in the activity of the western volcanoes suggested by the blanks in the summary (table 2) from about 1830 to the first decade of this century may be merely a

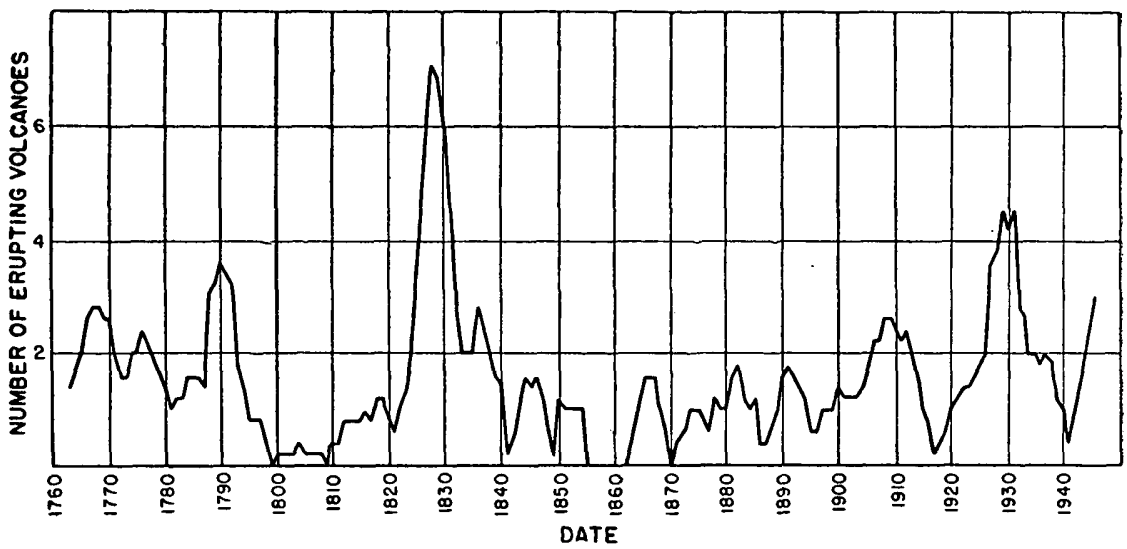

Figure 16.-Five-year moving averages of numbers of volcanoes in eruption in the Aleutian arc.

gap in reporting, due to the relative infrequency of travel in the western part of the arc during that period.

3. The well-known high frequency of activity on the part of Makushin, Shishaldin, and Pavlof is obvious from an inspection of the summary. Grewingk recognized that the mountains toward the eastern end of the arc are, on the average, higher than those toward the west. For mountains in the same stage of erosion, this may indicate more frequent activity, a longer history of activity, or more material erupted per unit of time.

The apparent periodicity indicated by figure 16 is the periodicity of the activity of the arc as a whole and not of any individual volcano, inasmuch as the volcanoes whose activities are represented by one maximum on the chart are not identical with those represented by other maxima. 


\section{NATURE OF VOLCANIC ACTIVITY}

Although the study of the vo.canoes of the Aleutian arc is far from completed (many of them have not yet been examined even in a reconnaissance way), certain general zations based on the work done to date may be offered with considerable confidence that they will not be invalidated by further work.

The older volcanoes of the ar(: seem to include both shield volcanoes, characterized by many relatively thin flows, with a small proportion of fragmental material, accumulated on slopes of iJw declivity, and stratovolcanoes or composite ccines, made up botr of flows and fragmental material, the slopes of which approach the angle of repose of the fragmental material. The major active volcanoes of the arc are without exception composity cones.

\section{CAIDERAS}

A striking feature of the Aleutian arc is the presence of many calderas, some of great size. For the purpose of this report, the definition of Williams (1941, p. 242) will be adopted: "Calderas are large volcanic depressions, more or less circular * * * in form * * *." The lower limit to the diameter suggested by Williams is 1 mile. The list that follows includes all calderas known to the writer at the date of writing (May 1949), but others doubtless will be discovered, especially where erosion has altered the characteristic topographic form sufficiently to disguise its origin. Many of the calderas in the list have been seen only from the air or in aerial photographs, but the characteristic form and relation to the structure exposed in the rimming cliffs are seldom ambiguous.

TABLE 3-Calderas of the Aleutian arc

\begin{tabular}{|c|c|c|c|}
\hline Name & Geographic loctlity & $\begin{array}{l}\text { Size, } 1 \text { in } \\
\text { kilometers }\end{array}$ & Source of information \\
\hline 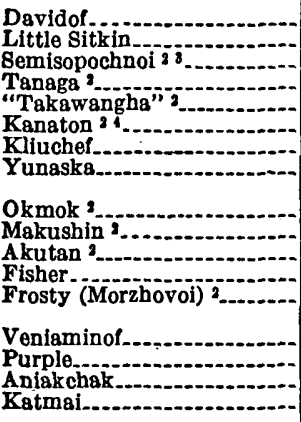 & $\begin{array}{l}\text { Davidof Island } \\
\text { Little Sitkin Islanil } \\
\text { Semisopochnoi Isle nd. } \\
\text { Tanaga Island... } \\
\text { Kanaga Island. } \\
\text { Atka Island } \\
\text { Yunaska Island } \\
\text { Umnak Island } \\
\text { Unalaska Island. } \\
\text { Akutan Island. } \\
\text { Unimak Island } \\
\text { Alaska Peninsula. } \\
\\
\\
\text { do do do }\end{array}$ & 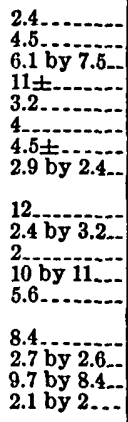 & $\begin{array}{l}\text { U. 8. Coast Pilot, Alaska, pt. 2, } \\
\text { 1947, p. 430. } \\
\text { Dunn, Robert, 1908, pp. 540-550. } \\
\text { Maddren, A., 1919, pp. 283-298. } \\
\text { Finch, R. H., 1935, pp. 155-160. } \\
\text { Waldron, H. H., personal com- } \\
\text { munication, 1948. } \\
\text { Knappen, R. S., 1929, pp. 203-204. } \\
\text { Do. } \\
\text { Smith, W. R., 1925, pp. 139-149. } \\
\text { Griggs, R. F., 1921. }\end{array}$ \\
\hline
\end{tabular}

1 One figure indicates diameter; where two figu es are given, caldera is notably elliptical.

Examined in the fleld since 1946 by the writer or his colleagues of the U. 8 . Qeological Survey.

- Cerberus Volcano (p. 38) is a younger central sone in Semisopochnoi Caldera; Sugarloaf lies outside it.

- Kanaga Volcano (p. 38) is a younger central ccine in Kanaton Caldera (C0ats, 1947, p. 89). 
The recognition of most of these calderas cannot be regarded as a yery difficult achievement; given the availability of detailed topographic maps or of aerial photographs. Where no source of information is given, the writer is the responsible source; otherwise, recognition of the caldera is credited to the first known observer describing it as such or, in the case of discoveries yet unpublished, to the first observer known to the author to have recognized its origin, regardless of whether he referred to it as a caldera or a crater.

It should be noted that the dimensions given are minima, scaled to the base of the lowest accessible part of the bounding cliff. This accounts for the fact that many of the dimensions are smaller than those in the original reports referred to.

\section{VOLCANIC DOMES}

The term "volcanic dome" is used to mean a steep-sided viscous protrusion of lava forming a more or less dome-shaped mass around its vent. (See Williams, 1932, p. 54.) Such protrusions are common, as Powers (1916) has shown, in the vicinity of many volcanoes of the circum-Pacific zone; commonly they occupy the summit crater and put a temporary or permanent halt to the activity of the cone. Others form on the flanks of the volcano. The volcanic domes of Novarupta, near Katmai, and of Bogoslof are well known; others have been described from Adak. Island (Coats, 1947, pp. 81-82) and from Great Sitkin Island (Simons and Mathewson, 1947, p..63). F. M. Byers, Jr., according to a.personal communication, has recognized an obsidian dome on Umnak and W. F. Thompson, Jr. $(1949$, p. 460), a dome in the crater of Mount Augustine. Domes are known to be present on Buldir Island, on Bobrof Island, in Kliuchef Volcano, and at the summit of Roundtop on Unimak. Many "plugs" mapped by Knappen on the flanks of Veniaminof and Aniakchak are probably domes. On the whole, however, domes are rare in the Aleutian arc compared, for example, with the southern part of the Cascade Range in Oregon and California.

\section{PETROGRAPHIC CHARACTER OF THE VOLCANIC ROCKS}

The volcanic rocks of the Aleutian arc range from olivine basalt to rhyolite. They include basalts characterized by olivine and andesites without olivine, in both of which hornblende and hypersthene occur separately or together. Relatively high percentages of conspicuous calcic plagioclase crystals and usually less conspicuous green augito characterize most of the rocks. Those that are comparatively rich in silica, such as dacites and rhyolites, are much less plentiful; most of them are presentit either as small bodiess of highly glassy. lava or as blankets of light-colored pumice. 


\section{RELATION OF :VOLCANISM TO STRUCTURE}

The most conspicuous posi ive element in the structure of the Aleutian arc is the great curvilinear ridge extending southward and westward to Attu from the Aleskan mainland, where it merges at the northeastern end with the Alaska Range. The ridge is notably wider at the eastern end than at the western. From it a branch about 300 miles long extends northwarcl and "westward from Semisopochnoi Island, forming a submarine jnountain ridge rising in places 12,000 feet above the sea floor.

The main ridge is bounded on the north by the lowlands of the Alaska Peninsula and by the Bering Sea. The eastern part of the Bering Sea, as far west as a line extending northwestward from Unimak Pass, is very shallow. T'he western part of the Bering Sea is deep, and large areas of the bottom form extensive plains at depths close to 2,000 fathoms ( 3,700 neters). On the south, the ridge of the Aleutian Islands is bordered by the Aleutian Trench (Murray, 1945), a typical marginal deep extending to depths of about 4,200 fathoms $-(7,700$ meters $)$.

In general, the volcanoes are superficial structures, built upon a basement of Tertiary and older rocks that is exposed at intervals throughout the length of the arc. The nature of the structures that have determined the position of the eruptive centers can be determined in few places:" Some writers have thought that the line of volcanoes, because of its narrowness, represents the trace of a great thrust plane or fault, movement on which is thought to be responsible for the frequent earthquakes. In detail, the volcanic line does not form a perfectly simple arc, but consists of segments of different lengths; the included angles between adjacent segments may be as little as $140^{\circ}$. Certain volcanoes, like Bogoslof and Amak, lie some distance away from the main.line, on the con save side of the arc. In the Aniakchak region, Knappen mapped a ten sion fault with an east-w.est trend, along or close to which several volca nic structures are alined; he considered that the site of the eruptive ce ater was determined by the existence of the fault. It is probable that similar relationships exist elsewhere in the arc and that most of the volcanoes have had their sites determined by minor tensional fractures. striking at an angle to the major overthrust zones. The distance o:: a volcano from the major active zone of movement is probably dependent upon the depth at which such a tensional fracture, originating; in and limited to an overthrust block, taps eruptible magma. The minor tensional faults, by this hypothesis, bear a spatial relationship to the hypothetical major active zone similar to that of the "feather fractures". of Cloos (1932, pp. 387-395).

$\therefore$ The distribution of earthquake foci (Gutenberg and Richter, 1941, p. $25 ; 1945$, pp. $654-655$ ) is such that the epicenters of shallow earth- 
quakes tend to be south of the chain; those of intermediate-depth earthquakes (deeper than 60 kilometers) are in the islands or north of the chain. It seems probable that the general structural picture of the Aleutian Islands, when more information is available, will resemble that presented by Gutenberg and Richter for the structurally similar Japanese arc (1941, p. 110). The distribution of deep and intermediate earthquake foci will probably fall along an active zone or surface, which will be shown to reach the surface of the crust along the northern slope of the Aleutian Trench and to dip northward at a moderate angle.

The older rocks of the Aleutian arc, in some places dating back to the Paleozoic, are both folded and faulted. The folding in general is relatively open, and dips are moderate. Major faults are reverse faults, trending nearly parallel to the trend of the arc; the north side has generally moved south and up with respect to the south side. In the Aniakchak area (Knappen, 1929, p. 207), the northwestern overthrust block has generally moved northeast and up with respect to the southeastern block. Tensional faults trending at an angle to the trend of the arc also have been noted.

\section{REFERENCES CITED}

Becker, G. F., 1898, Reconnaissance of the gold fields of southern Alaska, with some notes on general geology : U. S. Geol. Survey 18th Ann. Rept., pt. 3, pp. 1-86.

Capps, S. R., 1934, Notes on the geology of the Alaska Peninsula and Aleutian Islands : U. S. Geol. Survey Bull. 857-D, pp. 141-153.

Cloos, Ernst, 1932, "Feather joints" as indicators of the direction of movements on faults, thrusts, joints, and magmatic contacts: Nat. Acad. Sci. Proc., vol. 18, pp. 387-395.

Coats, Robert, 1947a, Geology of northern Adak Island: U. S. Geol. Survey Alaskan Volcano Investigations Rept. 2, pt. 5, pp. 72-85 (limited distribution).

- 1947b, Geology of northern Kanaga Island: U. S. Geol. Survey Alaskan Volcano Investigations Rept. 2, pt. 6, pp. 89-94 (limited distribution).

Dall, W. H., 1918, Reminiscences of Alaskan volcanoes: Sci. Monthly, vol. 7, pp. $80-90$

Doroshin, $\mathbf{P}, P_{1}, 1879$, 0 niektorykh vulkanakh; Russ, K. min. Gesell. Verh., 2d ser., vol. 25, p. 44, St. Petersburg (trans. by M. M. Elias).

Dunn, Robert, 1908, On the chase for volcanoes: Outing Mag., vol. 51, p. 546.

Finch, R. H., 1935, Akutan volcano: Zeitschr. Vulkanologie, Band 16, Heft 3, pp. 155-160.

Grewingk, Constantin, 1850, Beitrag zur Kenntniss der orographischen und geognostischen Beschaffenheit der Nordwestkïste Amerikas. mit den anliegenden Inseln, St. Petersburg, K. Kray (previously published in Russ. K, min, Gesell, Verh, 1848-49),

Griggs, R. F., 1921, The Katmai National Monument and the Valley of Ten Thousand Smokes: Science, vol. 49, pD. 236-237.

Gutenberg, Beno, and Richter, C. I., 1941, Seismicity of the earth: Geol. Soc. America Special Paper 34.

$\longrightarrow, 1945$, Seismicity of the earth : Geol. Soc. America Bull., vol, 56, pp. 603-658. 
Jochelson, Waldemar, 1933, History, ethnology and anthropology of the Aleut: Carnegie Inst. Washington Pub. 432, p. 7.

Knappen, R. S., 1929, Geology and mineral resources of the Aniakchak district: U. S. Geol. Survey Bull. 797-F, pp. 161-223.

Maddren, A. G., 1919, Sulphur on Unalaska and Akun Islands and near Stepovak Bay : U. S. Geol. Survey Bull. 692-E, pp. 283-298.

Murray, H. W., 1945, Profiles of the Aleutian Trench : Geol. Soc. America Bull., vol. 56, pp. 757-781.

Powers, Sidney, 1916, Volcanic domes in the Pacific: Am. Jour. Sci., 4th ser., vol. 42 , pp. 261-274.

Robinson, G. D., 1948, Exploring Aleutian volcanoes: Nat. Geog. Mag., vol. 94, no. 4 , pp. 509-522.

Sapper, Karl, 1927, Vulkankunde, pp. 338-342, Stuttgart.

Smith, P. S., 1939, Areal geology of Alaska: .U. S. Geol. Survey Prof. Paper 192, p. 80 .

Smith, W. R., 1925, Aniakchak Crater, Alaska Peninsula : U. S. Geol. Survey Prof. Paper 132-J, pp. 139-149.

Thompson, W. F., Jr., 1949, Observations in Kamishak, Alaska: Geog. Rev., pp. $450-471$.

United States Coast and Geodetic Survey, 1947, U. S. Coast Pilot, Alaska, part 2. Williams, Howel, 1932, The history and character of volcanic domes : Calif. Univ., Dept. Geol. Sci., Bull., vol. 21, no. 5, pp. 51-146.

, 1941, Calderas and their origin: Calif. Univ., Dept. Geol. Sci., Bull., vol. 25, no. 6, pp. 239-346. 



\section{INDEX}

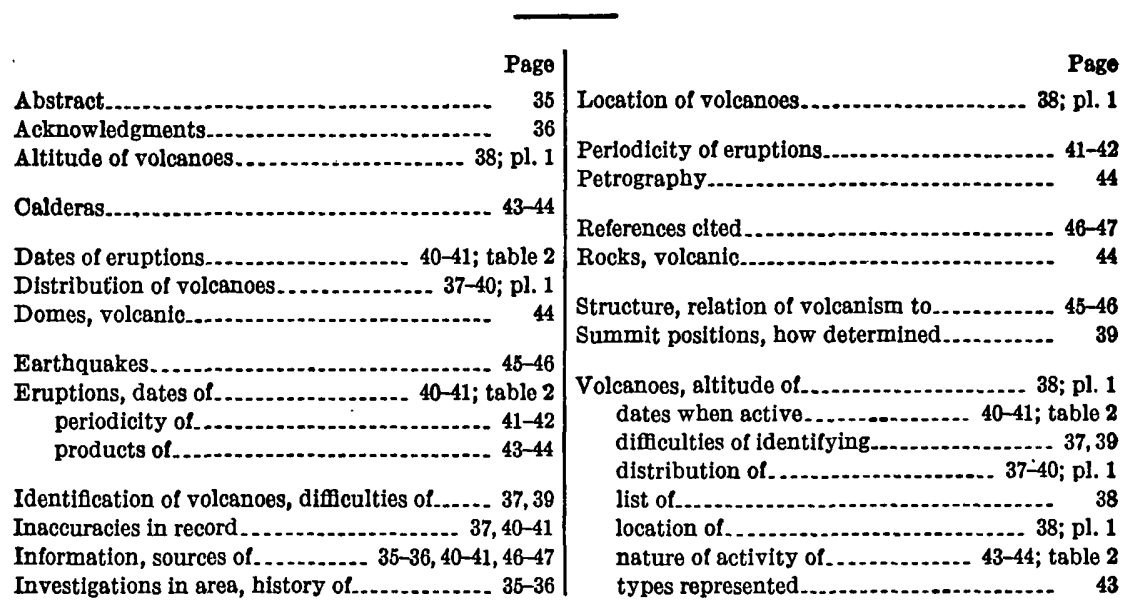

